\title{
Development of Teaching Materials Based On Digital Module in Pattern Construction Course for Fashion Education Students in State University of Medan (UNIMED)
}

\author{
Nurmaya Napitu $^{1 *}$, Flora Hutapea ${ }^{1}$, Rosita Carolina Sitorus ${ }^{1}$ \\ \{*imadiahmad1977@gmail.com\} \\ ${ }^{1}$ Department of Fashion Education, Universitas Negeri Medan, Indonesia,
}

\begin{abstract}
This research aims to: 1) to developer teaching materials based on digital module in pattern construction course, and 2) to find out the effectiveness of teaching material based on digital module in pattern construction course in fashion education section. The type of the research used in this study is Research and Development (R\&D). It uses the stages or procedures that have been adapted, which include: a) needs analysis; b) developing products; c) Validation and revision; d) Small group trials of 5 students; e) Medium group trials of 15 students, and f) large group trials; g) The final product. The subjects in this research trial are 30 fashion education students class of 2017. The expert validation consists of 2 media experts and 2 material experts, and learning design experts. Data collection tools are using in this research is questionnaires to trace the needs of lecturers and students. Validators and questionnaires for effectiveness include a rating scale with data analysis techniques using a Likert scale. Digital module developed with the Edmodo application network. The result of the research from media expert get a percentage of $87.33 \%$ with very good criteria and validation of the subject matter expert with a percentage of assessment results of $90.67 \%$ with very good criteria. 2) The results of a small group trial with a percentage of $76 \%$, with good criteria being medium with a medium group trial with a $78 \%$ percentage assessment with criteria and a large group trial with a percentage of $90 \%$, with very good criteria. 3) Testing the effectiveness of students with a percentage of $90 \%$ with very good criteria. Trial of effectiveness by lecturers with assessment percentage $92 \%$ get very good criteria. So, the development of teaching materials based on digital module in the construction course of Fashion Education Students in 2017 is considered effective and feasible to be used as learning media.
\end{abstract}

Keywords: Teaching materials, digital modules, pattern construction, effectiveness

\section{Introduction}

The success of learning can be seen from two interrelated aspects such as the process aspects and product aspects. The process aspect is determined by the role of the lecturer as the manager of teaching, namely as a planner or designer. Fathurrohman (2015) argues that the lecturers act as facilitators, managing various learning resources and facilities for students. So the success of the aspects of the process created and applied in learning will certainly affect the aspects of the product produced. The product aspects produced will be seen from the 
learning outcomes obtained by students. However, the success of students in processing new information given by lecturers is very dependent on the maturity of the students' thinking power. Therefore, the learning must be well designed and programmed, so we will get the active interaction between lecturers and students.

The pattern construction course is a compulsory and important subject consisting of those who experience various problems in learning. This course is a basic course that provides students with basic knowledge and skills about the basic concepts of pattern construction, construction patterns and standard patterns. Pattern construction is used as a guide in making clothing until eventually it is expected that students will be able to change the pattern and create clothes that are comfortable to wear and fit on the body. Based on the information, the observations and the observation result from the Pattern Construction learning process, it was found that the lecturer had applied several learning methods such as lectures, question and answer, discussion, practicum and assignment. Furthermore, based on the documentation of the scores (DPNA) of the students in Family Welfare Education department (PKK) in 2017, it was found that there were still many students who received learning outcomes that did not meet the minimum passing grade of 36 students who received an A score of $3(8.33 \%)$, a B score of $8(22.22 \%), \mathrm{C}$ is 12 people $(33.33 \%)$ and as many as 13 people $(36.11 \%)$ do not meet the minimum passing grade.

The low student learning outcomes are certainly influenced by various factors, among others, the learning methods that are applied are not in accordance with the lecture material, the lecture material obtained by students only comes from textbooks whose existence is not necessarily in accordance with the needs of students, even tends to existing textbooks not in accordance with the curriculum and competence of students. Based on the description above, an alternative effort is needed that needs to be developed by the lecturer in Pattern Construction. One of them is by developing learning materials through the development of teaching materials. .

This of course refers to PP No. 19 of 2005 Article 20 that is suggested that lecturers are expected to develop their own learning material. Then confirmed through the Minister of National Education Regulation (Permendiknas) number 41 of 2007 concerning process standards, among others regulating the planning of the learning process which requires educators in education units to develop learning implementation plans (RPP), one of which is a learning resource as an important element in an RPP. Thus, it is expected that lecturers can develop learning materials as part of learning resources.

According to [1] that teaching material is a set of facts, concepts, principles, procedures, and or generalizations that are specifically designed to facilitate teaching. Teaching materials serve as guidelines for lecturers and students about the substance of competence that should be taught to students and must be mastered / studied by students. Teaching materials can be in the form of textbooks, modules, films, compact disks (CDs), multimedia interactive learning and web-based modules (web based learning materials) or digital modules.

The development of information technology, especially internet technology can be used as an alternative to making effective and efficient learning modules. The use of E-Learning in learning has the advantage of saving learning time, reducing travel costs, saving costs, reaching a wider area and training more independent students in gaining knowledge.

Based on the description above, it can be assumed that the need to develop teaching materials in the form of digital modules that can be accessed and obtained by students anywhere and anytime, so that students are easy to learn and understand learning materials that are expected to improve student learning outcomes. 


\subsection{Formulation of the problem}

The formulation of the problem in this study is:

(a) How to develop Digital Module teaching materials in the Pattern Construction course of the Fashion Education Study Program?

(b) How to test Digital Module teaching materials in the subject of Pattern Construction in the Fashion Education Study Program?

(c) How is the effectiveness of the pattern construction course for the students in Fashion Education Study Program by using Digital Module?

\subsection{The Objective of the Study}

In general, the purpose of this research is to solve the problems mentioned above, then research the development of Pattern Construction Digital Module teaching materials. The purpose of this research specifically is to find out:

(a) Development of Digital Module teaching materials in the Pattern Construction course in Fashion Education Study Program.

(b) The results of the trial of the Digital Module teaching materials in the Pattern Construction course in the Fashion Education Study Program.

Effectiveness of the pattern construction courses of students in the Fashion Education Study Program by using Digital Module

\section{Methodology}

\subsection{Development of Learning Materials Based on Digital Modules}

Teaching materials are a set of materials that are arranged systematically to create an environment / atmosphere that allows students to learn. According to [2] states that teaching materials are all forms of materials, information, tools and texts that are used to assist lecturers in carrying out teaching and learning activities. The instructional material in question can be in the form of writing or not written. Teaching materials or curriculum materials are content or curriculum content that must be understood in an effort to achieve the curriculum objectives. One form of teaching material is a module.

\subsection{Characteristics of Learning with Modules}

In order to produce a module that can increase the user's motivation, the module must include characteristics:

\section{1) Self instructional.}

Self instructional is an important characteristic in the module. With these characters allows one to learn independently and not depend on others. To fulfill this character, the module must.

\section{2) Self contained}

Self contained is the whole learning material from a competency unit or sub competencies that are studied contained in one module in its entirety. If in a module the division or separation of material from one competency unit must be done carefully and pay attention to the freedom of competence that must be mastered by students. 


\section{3) Stand Alone}

Multimedia modules that are developed are not dependent on other media to study and work on module tasks

4) Adaptive

The module should have high adaptive power to the development of science and technology. Modules can adapt science and technology.

5) Userfriendly

The module should be friendly to the user, including instructions and information exposure that are helpful, easy to understand, and use general terms.

\subsection{The Role of the Modules in Learning Activities}

The modules are very important for lecturers and students in the learning process. Without the modules, it will be difficult for lecturers to improve the effectiveness of learning. Likewise with students, without modules it will be difficult to adjust to learning. Therefore the module is considered as an additional teaching material that can be used, both by lecturers and students as an effort to improve the quality of learning. The role of modules for Lecturers and Students:

(1) Save lecturer time in teaching

(2) Students can learn by themselves without having to exist lecturer or other friend

(3) Changing the role of the lecturer from a teacher to a facilitator Students can learn anytime and anywhere they want

(4) Improving the learning process to be more effective and interactive Students can learn according to their own pace

(5) Students can study according to the order they choose

(6) Helping students to be more independent [3]

With the learning module it is assumed that students will be motivated to read and study independently without being dependent on the lecturer. Finally students find the desired capability or study. The more concrete students learn teaching materials, the more experience they get. In determining the scope or scope of learning material needs to pay attention to several aspects, namely: (1) cognitive aspects which include knowledge, understanding, application, synthesis, analysis and assessment; (2) Affective aspects which include giving responses, appreciation, assessment and internalization and (3) Psychomotor aspects which include initial movement. In the preparation of the module can be done according to the following format:

(a) Cover page

The page can also add the author's name, meeting to what number, subject name, and other important information

(b) Subjects Adjusted to Standard Competence

(c) Description Contains a brief description of content and description of the material contained in the module

(d) Prerequisites Basic abilities should be owned by students

(e) Glossary terminology

(f) Instructions for using the Contains module instructions and procedures for using the module

(g) Basic Vocational Competency

(h) Basic competencies are usually designed to be some learning activities depend on breadth and depth of material 
(i) The purpose of Module Learning consists of several learning objectives are appropriate with those listed in the syllabus and RPP Learning objectives are written briefly butdescribe the entire contents of the material learning.

(j) Description of the description of the description is presented in the form sequentially so that the writer is in front the reader. Include complete examples and clear.

(k) Formative Test Aims to measure student learning progress in one unit learning. Provision of objective tests make it easy for students to do measurement (giving value) above his own ability.

(1) Bibliography Lists bibliography and used as a source in the preparation of modules.

\subsection{The Nature of Pattern Construction Courses}

The Pattern Construction course is a compulsory and basic subject at the Department of PKK in Faculty Engineering, State University of Medan. The purpose of the Pattern Construction course is for students to understand the basic concepts of pattern construction, both the system of construction patterns and standard patterns. In this case students are expected to have knowledge and skills in making basic patterns of body, arms and skirts and breaking patterns according to the model. In order to achieve the learning objectives, students must master several patterns of pattern construction, namely the basic pattern with a coup on the waist and sides, the basic pattern with a coupe on the waist and fittings.

The competency standard in the Construction Pattern course is to understand and be skilled in constructing patterns, both in the construction of children's, women's and men's fashion patterns in construction. Material description in Pattern Construction courses are formulas that need to be understood in taking measurements and drawing various patterns. Therefore, the learning will be better if supported by the learning media, so that it can help students to more easily understand the material that has been explained by the lecturer.

The study was conducted in the Class-A Fashion Education Program -Department of Family Welfare Education (PKK) - Faculty of Engeneering - State University of Medan (UNIMED). When the research was conducted, the odd semester of the 2018/2019 school year took place from July to October 2018.

The development model is the basis for developing products that will be produced. According to Sugiono (2015) the steps of research and development are: 1) determine potential and problems, 2) data collection, 3) product design, 4) product design validation, 5) product design revision, 6) product trials, 7) usage test, 8) Revision of Data Collection Technique products

Data collection methods are the main step of research, with the intention of getting accurate and accountable data. Data collection techniques in this study were carried out in several ways, namely: 1) Observation 2) Interview 3).

\section{Results And Discussion}

\subsection{The Instrument for Collecting the Data}

The techniques for collecting the data are the method taken to obtain data in accordance with the data needed. The instrument used in this study is by using Questionnaire. The questionnaire aims to determine aspects to develop teaching materials based on digital modules in the opinion of lecturers, especially pattern construction courses. Furthermore, the 
data obtained is used as a reference for the development of teaching materials through the Edmodo application digital module.

\subsection{Analysis of the Data}

Analysis of the data used in the development research is descriptive statistics that describes the steps in developing digital module-based interactive learning media in the Pattern Construction course and illustrates the results of the effectiveness of learning media. To test the effectiveness of learning media in the Pattern Construction engineering course, several stages were carried out, namely the validity test by media and material experts, group trials and lecturer responses.

The results of the feasibility test of the learning media from the views of 2 media experts if presented in the bar diagram are as follows:

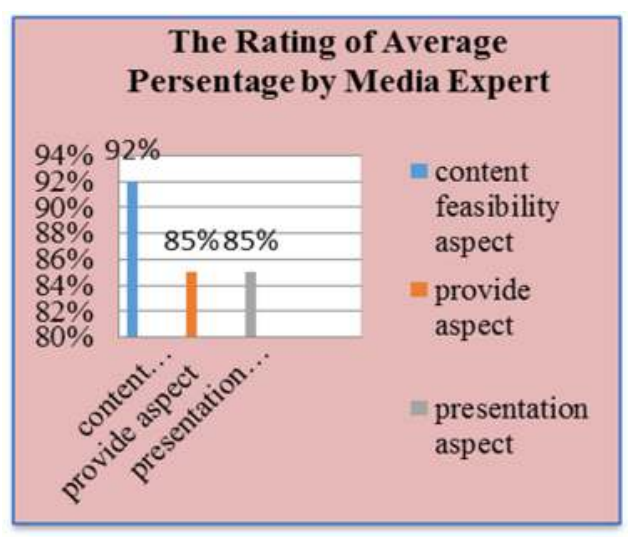

Fig. 1. Average Percentage Diagram by Media Expert

Feasibility test of learning media by media experts with a percentage of $92 \%$ based on the feasibility aspects of media content. Based on the presentation aspect of learning media with a percentage of $85 \%$. Based on the feasibility aspect of the percentage by media experts with a percentage of $85 \%$ research media learning with a percentage of $87.33 \%$ so that it falls into the criteria of very good / very feasible / very good to use as a learning medium. The results of the feasibility test of the learning course from the viewpoint of 2 expert material if presented in the bar diagram as follows:

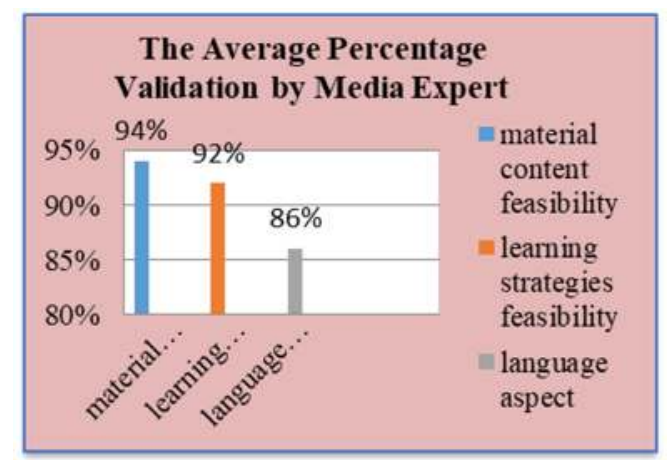

Fig. 2. Average percentage diagram by the material expert 
Feasibility test of learning courses by material experts with a percentage of $94 \%$ based on aspects of the feasibility of the contents of the course. Based on aspects of the learning media strategy with a percentage of $92 \%$. Based on the feasibility aspect of the learning media language with a percentage of $86 \%$. Based on all aspects of the study of learning material with a percentage of $90.67 \%$ so that it is included in the criteria of very good / very decent / very good to use as a learning medium.

Based on the results of the assessment of the effectiveness of digital module-based teaching materials by lecturers and students of the Fashion Education Program - Department of PKK - UNIMED

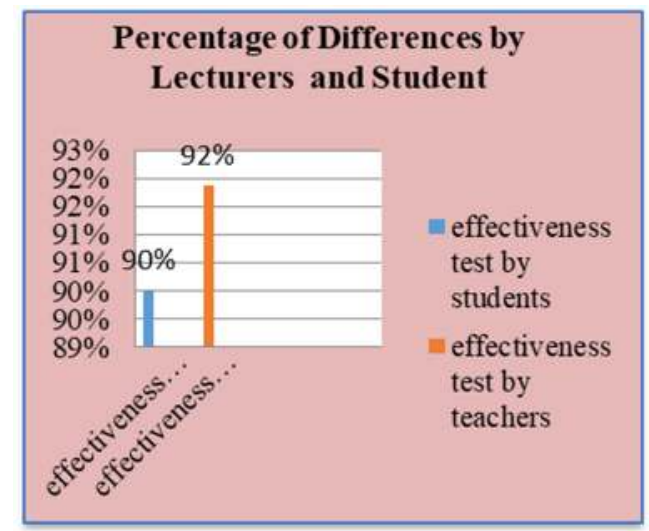

Fig. 3. Percentage of Differences by Lecturers and College student

The test results of the effectiveness of instructional media by students get a percentage of $90 \%$ so that it belongs to the category of very feasible and while the results of the effectiveness test of instructional media by the lecturer gets $92 \%$ so the learning media is very feasible to use.

\subsection{Research Discussion}

This development research was carried out in several stages which Sugiono put forward, which was simplified into seven stages, which included the analysis of student needs, the stage of product development, subject validation of the subject matter and revision, the small group trial stage, the large group trial stage and the test stage. try a large group.

In the results of the validation sheet which was assessed by media experts $87.33 \%$ that the media was worthy of use because of the good appearance of the image, the animation was good. Student attention increases so as to create interesting and efficient learning. Then the material expert gave an assessment of $90.76 \%$ that the module was suitable for use in the teaching and learning process because the language used was easily understood and in accordance with the RPP and lecture contracts.

In the results of the questionnaire responses of students and lecturers that have been conducted, the learning media of Pattern Construction courses received a $90 \%$ response in criteria "very good results of the effectiveness of the instructional media test by the lecturer got $92 \%$ so that the learning media is worthy of use 


\section{Conclusion}

Based on the development research conducted and the discussion that has been described can be concluded in this study as follows:

a. The results of the development of digital module-based teaching materials at the Fashion Education Program - Faculty of Engineering were assessed by an overall media expert $87.33 \%$ with a "very good" criteria and an assessment of the subject matter expert at $90.67 \%$ with a "very good" criteria so that the media Digital modulebased teaching materials are suitable for use as learning media in pattern construction courses.

b. The trial results of the development of digital module-based teaching materials concluded that the learning module media that was developed were included in the excellent category with the overall value of media experts $90.67 \%$ of the results of small group trials $76 \%$ medium group test results $79 \%$ and test a large group of $90 \%$ has been eligible for production as a learning medium.

c. The product of teaching materials based on digital modules is concluded that effective learning media are used as learning media for pattern construction courses in the Fashion education program- Faculty of Engineering -UNIMED. Based on the results of students responses to the effectiveness test, the criteria were obtained with very good criteria with an average percentage of $90 \%$ and the teacher's response was considered very good with an average percentage of $92 \%$.

\section{Suggestion}

Based on the discussion of the results of the study, the authors show some suggestions for improving and further research as follows:

(1) It is expected that lecturers should have the willingness to make learning media so that learning and teaching processes are more interesting and interactive and can increase students' motivation in learning in pattern construction subjects.

(2) We recommend that the teaching and learning process such as lectures that have been carried out in the learning process is assisted by learning to use digital modules based teaching materials that can have a positive influence on students' interests, motivation and learning outcomes.

(3) For lecturers who will conduct research on the development of learning tools for eye construction patterns in order to produce better learning and multimedia media

\section{References}

[1] Y. Abidin, Desain Sistem Pembelajaran Dalam Konteks Kurikulum 2013. Bandung: PT. Refika Aditama, 2014.

[2] Majid, Metodologi Penelitian Pengembangan Untuk Peningkatan Kualitas Pembelajaran (Research Metodology to Improvement of Introduction). Bandung: Gransindo, 2014.

[3] Belawati, Direktorat Pendidikan Menengah Kejuruan Departemen Pendidikan Nasional tahun 2003. UU RI No. 20 Sistem Pendidikan Nasional. Jakarta: Depdiknas, 2013. 